\title{
INFLUENCE OF FERMENTATION AND COWPEA STEAMING ON SOME QUALITY CHARACTERISTICS OF MAIZE-COWPEA BLENDS
}

\author{
S. Sefa-Dedeh,Y. Kluvitse and E.O. Afoakwa* \\ Department of Nutrition \& Food Science, University of Ghana \\ P. O. Box LG 134, Legon-Accra, Ghana. (*author for correspondence) \\ *E-mail:e_afoakwa@xmail.com Tel/Fax: 233-21-500389
}

\begin{abstract}
Fermentation and cowpea steaming can be used to improve the protein quality and quantity of fermented maize dough. In the production of maize-cowpea blends, it is important that the quality characteristics are evaluated to determine their functionality in the products. A $5 \times 4 \times 2 \times 2$ factorial experiment with cowpea level, fermentation time, cowpea steaming time and fermentation method as the variable was performed. The cowpeas were dehulled, steamed, dried at 65EC for 24 hours and milled into flours. Maize was soaked in water (18 hours), drained and milled into flour. The maize-cowpea blends were made into a $50 \%$ moisture dough, fermented for the specified periods, dried at 65EC and milled into flour. Samples were evaluated for $\mathrm{pH}$, titratable acidity, water absorption and sugars. The $\mathrm{pH}$ and titratable acidity of the samples were affected by fermentation time, steaming time, and the levels of cowpeas in the blend. Cowpeas was the main source of glucose/galactose. Fermentation caused a reduction in stacchyose and glucose/galactose. The mixing of cowpea flour with fermented maize dough prior to drying (single component fermentation) gave similar effects on sugar concentrations as detected in the co-fermented samples (multi-component fermentation). Fermentation and steamed cowpea fortification can be used to produce high protein fermented cereal foods with reduced anti-nutritional factors.
\end{abstract}

Key words : Fermentation, steamed cowpeas, cowpea fortification, chemical composition, functional properties, weaning foods.

\section{INTRODUCTION}

Fermentation is widely applied in the processing of cereals for the preparation of a wide variety of dishes in developing countries (Obiri-Danso,1994). In Ghana, over $90 \%$ of cereal based traditional foods are prepared from fermented maize dough. The soaking of the grains in excess water allows the selection of desirable micro-organisms, such as lactic acid bacteria, yeasts, and moulds (Sefa-Dedeh et al., 1999; Sefa-Dedeh \& Cornelius, 2000). The activity of these microorganisms reduces $\mathrm{pH}$ and increases the titratable acidity of the substrate. A number of fatty acids are also produced (Akinrele,1970; Plahar \& Leung, 1982). Mensah et al. (1990) studying the properties of fermented maize dough observed significant inhibition of pathogenic bacteria. Cooking the dough into porridge reduced the antimicrobial effect but there was still significant inhibition of pathogens. The antimicrobial property could be an important strategy for the reduction of the high levels of faecal bacteria in cereal foods in the developing countries
Most African traditional gruels are made from cereals and the result is gruels that have low nutritional value as they are not adequate sources of micro- and macro-nutrients (Brown,1991). During cooking, the starch binds water, requiring considerable amounts of water to bring the consistency of the porridge to a level suitable for child feeding. This lowers the energy and nutrient density of the porridge considerably. This high volume/high viscosity characteristic referred to as dietary bulk makes it difficult for infants fed on these gruels to satisfy their nutrient requirement, which is considered as a major problem of malnutrition in areas where cereal staples are the main foods (Ljungqvist et al., 1981). Recently, more attention has been directed towards the fulfilment of protein energy requirements because of the widespread occurrence of protein energy malnutrition (PEM) and linear growth retardation in developing countries. The techniques commonly employed in traditional weaning food developments, include the formulation of high quality protein mixes (foods) using cereals and legumes such as cowpeas and soybeans. 
The application of cowpea-fortification to fermented cereal porridges have been reported to increase the nutritive value. As well, the total nutrient density increases by more than two-folds as a result of reduction in viscosity (Marero et al., 1980; Afoakwa,1996; Sefa-Dedeh et al, 2000). Cowpea steaming has been developed to control the infestation of cowpea seeds during storage. It involves the exposure of cowpea seeds to steam followed by drying to acceptable storage moisture contents. Sefa-Dedeh and Demuyarko (1994) investigated the effects of steaming and storage on some physico-chemical properties of cowpea seeds and flour. They reported that whilst the steaming resulted in an increase in water absorption capacity of the flour samples, the steamed seeds showed reduced water absorption capacities. They also observed characteristic differences in the viscoamylograph data following steaming, which is an indication of the ease of cooking of the samples. Further studies on some chemical and functional properties of steamed cowpea fortification to weaning foods will provide insight into the compatibility of steamed cowpea as a food ingredient and the success with which steamed cowpeas can be incorporated into various weaning foods.

This study was aimed at investigating the influence of fermentation and steamed cowpea fortification on some chemical and functional properties of fermented maizecowpea blends.

\section{MATERIALANDMETHODS}

\section{Materials}

Maize (Zea mays) and cowpea (Vigna unguiculata) were used in the experiments. An improved variety of maize (Abeleehi) was purchased from Ejura Farms, Accra. Dent corn and Blackeye peas obtained from the Centre for Food Safety and Quality Enhancement (CFSQE), University of Georgia, Atlanta and used for the study. All the samples were stored at a cold room $\left(4^{\circ} \mathrm{C}\right)$ during the study period.

\section{Sample preparation}

Whole cowpeas were soaked in water for 4 minutes to loosen the seed coats. The seeds were drained and dehulled using a disc attrition mill (Agrico Model 2A, New Delhi). The hulls were separated by floatation in water. One portion was dried in an oven temperature of $65^{\circ} \mathrm{C}$ for a period of 20-24 hours and the remaining portion steamed for 4 minutes. Subsequently, the steamed seeds were oven dried at $65^{\circ} \mathrm{C}$ and milled into flour using a disc attrition mill (Agrico Model 2A, New Delhi). Whole maize grains were soaked in water $(1: 3, \mathrm{w} / \mathrm{v})$ at $28^{\circ} \mathrm{C}$ for 18 hours. The steep water was drained and the grain milled using a disc attrition mill (Agrico Model 2A, New Delhi). Several formulations were prepared by the addition of weighed portions of dehulled and steamed cowpea flour to maize meal before fermentation. The resulting meal was kneaded into a 50\% moisture dough, allowed to ferment at room temperature for a period of 0 - 72 hours. Other blends were formulated by the addition of cowpea flours to the maize dough after fermentation. The preparations were dried in an oven at $65^{\circ} \mathrm{C}$ and milled into flour.

\section{Experimental Design :}

A $5 \times 4 \times 2 \times 2$ factorial experimental design was used and the principal factors were:

i. Cowpea level : 0, 5, 10, 15 and $20 \%$;

ii. Fermentation time : 0, 24, 48 and 72 hours;

iii. Steam treatment : 0 and 4 minutes,

iv. Fermentation method : Single and multiple component.

Samples were evaluated for $\mathrm{pH}$, titratable acidity, water absorption, and mono-, di- and oligosaccharides.

\section{Methods \\ pH and titratable acidity}

Ten grams of dried flour was mixed with $100 \mathrm{ml}$ distilled water. The mixture was allowed to stand for 15 minutes, shaken at 5 minutes intervals and centrifuged at $3000 \mathrm{rpm}$ for 15 minutes using a Denley centrifuge (Model BS4402/ D, Denley, England). The supernatant was decanted and its $\mathrm{pH}$ was determined using a $\mathrm{pH}$ meter (Model HM-30S, Tokyo, Japan). Ten (10)ml aliquots (triplicate) were titrated against $0.1 \mathrm{M} \mathrm{NaOH}$ using $1 \%$ phenolphthalein as indicator. Acidity was calculated as grams lactic acid/100g sample.

\section{Water absorption capacity}

Five grams of sample was weighed into a centrifuge tube and $30 \mathrm{ml}$ of distilled water at temperatures of 25 and $70^{\circ} \mathrm{C}$ added independently for the analysis at 25 and $70^{\circ} \mathrm{C}$ respectively. The mixture was stirred and allowed to stand for 30 minutes and centrifuged using a Denley centrifuge (Model BS4402/D, Denley, England), at $3000 \mathrm{rpm}$ for 15 minutes. The supernatant was decanted and the increase in weight noted by weighing. The water absorption capacity was expressed as a percentage of the initial sample weight. The determination was done for duplicate samples. 


\section{Determination of mono-, di- and oligosaccharides}

Sugars were extracted from maize/cowpea blends using a mixture of chloroform : methanol $(1: 1, \mathrm{w} / \mathrm{v})$ and water as in Havel, Tweeten, Seib, Wetzel and Liang (1977). Extract was concentrated under vacuum, made to $5 \mathrm{Ml}$ with de-ionized water. The extract was filtered with $0.22 \mathrm{~m}$ PTFE filters and stored in $5 \mathrm{~mL}$ ampoules at a cold room temperature of $0^{\circ} \mathrm{C}$. Ten microlitres $(10 \mu \mathrm{m})$ samples were analyzed by High Performance Liquid Chromatography (HPLC) using a Hitachi system equipped with a Hewlett Packard Integrator and Shimadzu Refractive Index Detector. Separation was done on a 220 x $4.6 \mathrm{~mm}$ amino propyl column (amino-spheri5, Brownlee Labs, Santa Clara) eluted with a 70:30 v/v mixture of acetonitrile : water which contained $0.01 \%$ tetraethylene pentamine (TEPA) as recommended by Aitzemuller (1978). Quantification was against authentic external standards of the sugars detected and a lactose internal standard.

\section{Statistical analysis}

The data obtained from the chemical and functional determinations were statistically analyzed using Statgraphics (Graphics Software System, STCC, Inc. U.S.A). Comparisons between sample treatments and the indices were done using analysis of variance (ANOVA) with a probability $\mathrm{p}<0.05$.

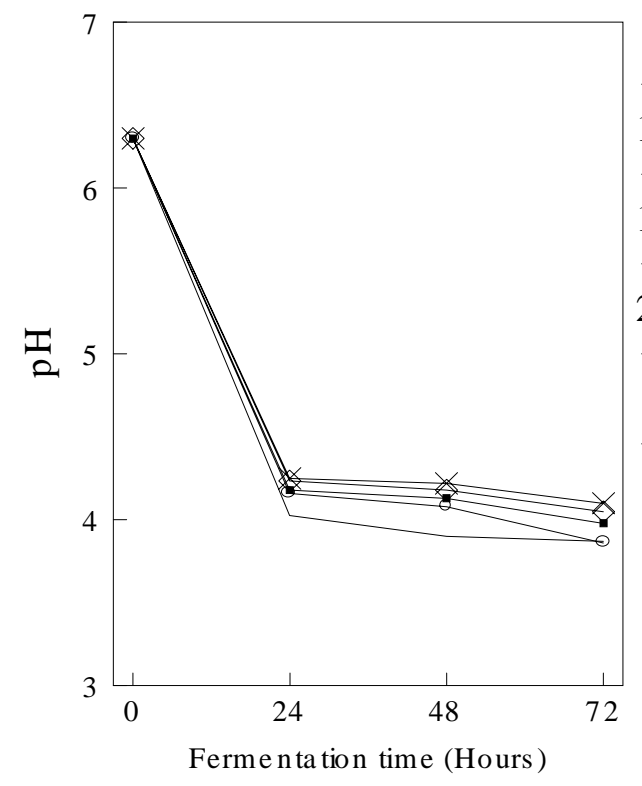

\section{RESULTS AND DISCUSSION}

\section{pHand acidity}

The solid-state fermentation of maize dough had a drastic effect on $\mathrm{pH}$. Within the first 24 hours of fermentation, the $\mathrm{pH}$ decreased from 6.3-4.0 (Fig. 1). After 72hrs of fermentation, the $\mathrm{pH}$ of the dough was 3.87. Fortification with up to $10 \%$ of unsteamed cowpea yielded fermented dough with comparable $\mathrm{pH}$ as the unfortified maize dough. Samples containing 15-20\% unsteamed cowpea however showed a relatively high $\mathrm{pH}$ (Fig. 1A).

The proteins in the cowpea may have contributed to the high $\mathrm{pH}$. Steaming of cowpea prior to addition to maize appeared to promote fermentation (Fig.1B). These samples had relatively lower $\mathrm{pH}$ than their unsteamed samples. Fortification up to $20 \%$ steamed cowpea provided samples with comparable $\mathrm{pH}$ as the $100 \%$ maize samples. The data suggests that maize can be fortified with up to $20 \%$ level and fermented to produce a dough with low $\mathrm{pH}$. Analysis of variance on the data showed that only fermentation time had a significant effect $(\mathrm{p} \leq 0.05)$ on dough $\mathrm{pH}$. Duncan's multiple comparison tests indicated that the unfermented maize samples were distinctly different from the fermented maize samples. The samples fermented for 24 hours were significantly different from those fermented for 72 hours. The 48 hour-fermented samples however

Figure 1. Effect of steam treatment and cowpea concentration on the pH of unsteamed (A) and steamed (B) cowpeafortification at concentrations of $0-20 \%$ of fermented maize-cowpea blends 
compared favourable with the other two samples (Table 1).

Table 1. F-ratios of process variables of the functional properties

\begin{tabular}{lccc}
\hline Process variable & $\mathbf{p H}$ & Acidity & Water absorption \\
\hline Fermentation time & $65.175^{*}$ & $187.35^{*}$ & $14.783^{*}$ \\
\hline Cowpea level & 0.2815 & 1.917 & $6.786^{*}$ \\
\hline Steam treatment & 0.343 & 0.387 & 0.009 \\
\hline * Significant F-ratios at $\mathrm{p} \leq 0.05$ & &
\end{tabular}

The major carboxylic acids produced during the fermentation of maize dough have been identified as lactic, butyric, acetic and propionic acids (Plahar \& Leung, 1982). The acidity of maize dough increased with fermentation. The addition of unsteamed cowpea lowered the acidity of the maize dough (Fig. 2A).

Steaming the cowpea prior to the addition to maize led to increases in acid production during fermentation for upto 48 hours. However, acidity decreased slightly during the final 24 hours of the fermentation period monitored (between 48 and 72 hours). Analysis of variance on the data showed that fermentation time had a significant (p\#0.05) effect on acidity. In addition the acidity level associated with each fermentation time was dependent on whether the cowpea has been steamed (Table 1) the ability of the cowpea-fortified maize dough system to ferment and produce acids comparable to the traditional maize dough system is beneficial. Mensah et al. (1990) reported that the antimicrobial properties of fermented maize dough due to the acids produced during fermentation. This was reported to reduce incidence of diarrhoea in infants consuming fermented maize porridge. The cowpea-fortified maize dough will have two important attributes, such as antimicrobial properties and high protein content. This will make it useful in the formulation of weaning foods.

\section{Sugars and Oligosaccharides}

\section{Cowpea}

Xylose, fructose, glucose, galactose, sucrose, maltose, raffinose and stachyose were determined in different concentrations in whole cowpea (Table 2). Dehulling led to an increase in the concentration of all sugars except for maltose, glucose and galactose. This suggest that maltose, glucose/galactose are concentrated in almost all the sugars with the exception of sucrose, glucose and galactose. The "-galactosides are known to constitute the major portion of sugars in legumes seeds (Fleming, 1980). Stacchyose was observed to be the major oligosaccharide, followed by raffinose in the cowpea samples as reported by other workers (Akpapunam \& Markakis, 1979; Abdel-Gawad,
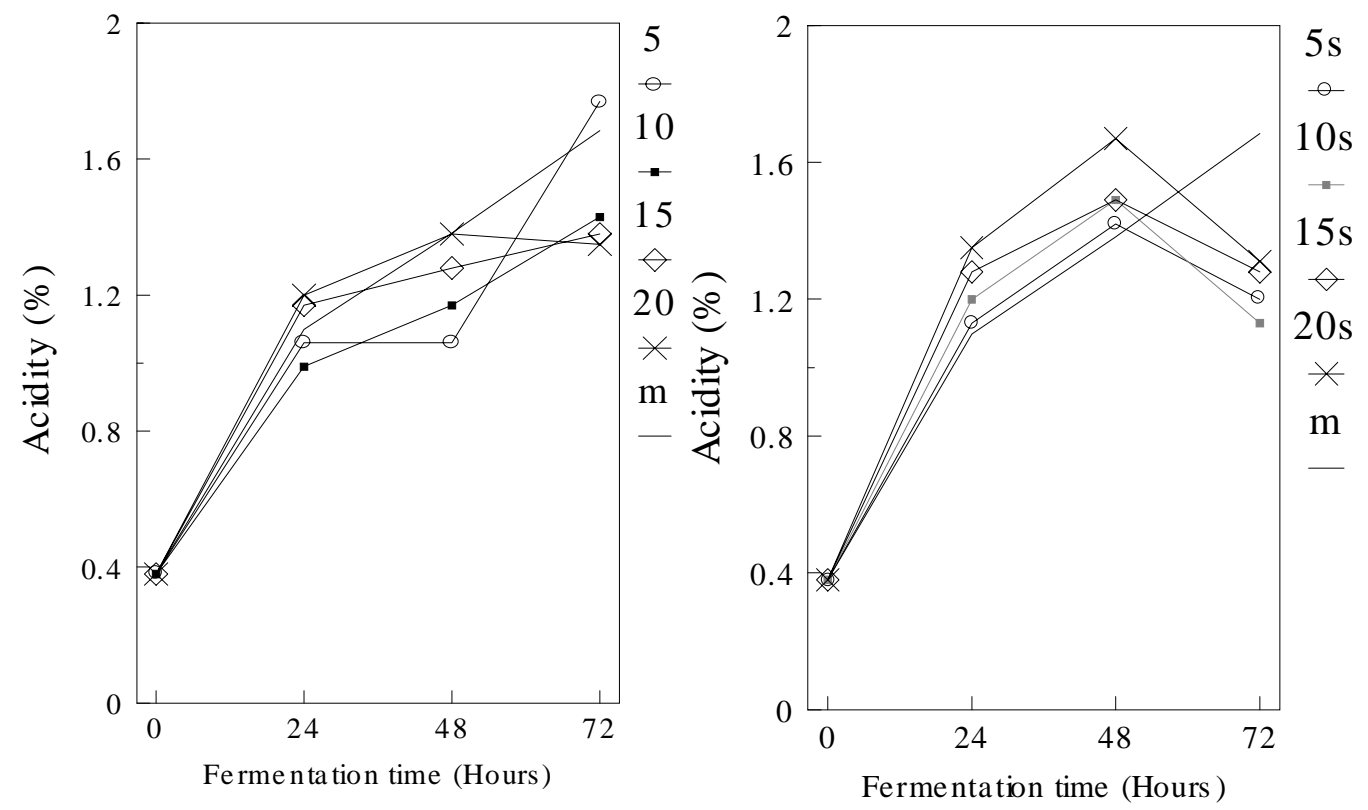

Figure 2. Effect of steam treatment and cowpea concentration on acid production of unsteamed (A) and steamed (B) cowpea-fortification at concentrations of $0-20 \%$ of fermented maize-cowpea blends 
Influence of Fermentation and Cowpea Steaming on some

Quality Characteristics of Maize-cowpea Blends

1992; Sosulski et al., 1982). The levels of stacchyose and raffinose increased with dehulling. This observation was contrary to initial studies reported by Akinyele and Akinlosotu (1991) who detected a decrease in oligosaccharide levels after dehulling cowpea seeds. The longer pre-soaking period of 4 hours allowed in their experiment might have facilitated leaching or initiated the process of fermentation in the seed resulting in increased "-galactosidase activity on the oligosaccharides.

Table 2. Levels of mono-, di- and oligosaccharides determined in cowpea (Vignia unguiculata) samples (mg/100g dry matter)

\begin{tabular}{lccccccc}
\hline $\begin{array}{l}\text { Cowpea } \\
\text { sample }\end{array}$ & Xylose & Fructose & $\begin{array}{c}\text { Glucose }+ \\
\text { Galactose }\end{array}$ & Sucrose & Maltose & Raffinose & Stachyose \\
\hline Whole & 0.38 & 0.012 & 0.337 & 1.652 & 0.118 & 0.552 & 2.545 \\
Dehulled & 0.612 & 0.436 & 0 & 1.828 & 0.051 & 0.63 & 3.661 \\
Dehulled \& & 0.332 & 0.068 & 0.028 & 2.034 & 0.039 & 0.234 & 3.34 \\
Steamed & & & & & & &
\end{tabular}

Maize

Maize was observed to have high concentrations of glucose and galactose. Other sugars detected in the maize were maltose, xylose and fructose (Table 3 ). The effect of fermentation on the concentration of the sugars varied. During the first 24 hours of fermentation, the concentration of fructose, glucose and galactose decreased. Xylose and

A B
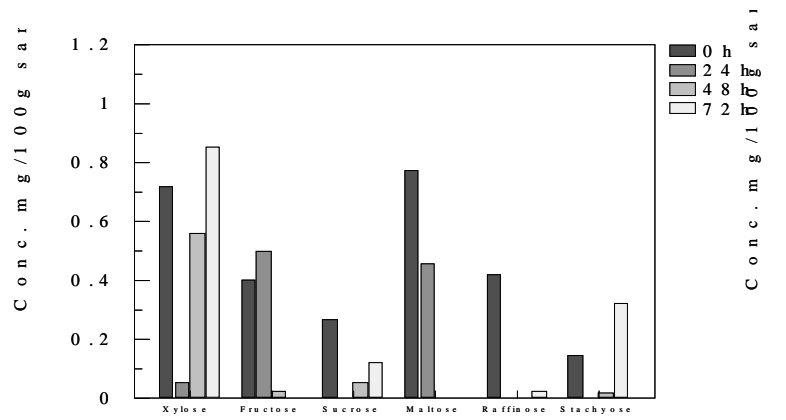

maltose however showed a slight increase in concentration. Further fermentation for 24 hours showed an increase in all the sugars except xylose. Fermentation for 72 hours showed a drastic reduction in the concentration of glucose/ galactose and maltose (Table 3). The levels of maltose, glucose and galactose appeared to increase during the first 48 hours of fermentation and drop drastically after 72 hours. Sucrose, raffinose and stacchyose were not detected in the maize samples.

Table 3. Levels of mono-, and disaccharides as determined in maize (Zea mays) samples (mg/100g dry matter)

\begin{tabular}{lcccc}
\hline $\begin{array}{l}\text { Fermentation } \\
\text { Time (Hours) }\end{array}$ & Xylose & Fructose & $\begin{array}{c}\text { Glucose }+ \\
\text { Galactose }\end{array}$ & Maltose \\
\hline 0 & 0.705 & 1.093 & 9.636 & 0.21 \\
24 & 0.788 & 0.678 & 9.566 & 0.277 \\
48 & 0.481 & 0.69 & 10.213 & 0.438 \\
72 & 0.473 & 0.597 & 1.056 & 0.14 \\
\hline
\end{tabular}

\section{Co-fermentation}

Fermented maize and cowpea blends showed varied effects of process variables on sugar and oligosaccharide concentrations. In the system in which cowpea was cofermented with maize (Figs. $3 \& 4$ ) the effects of process

\section{D}
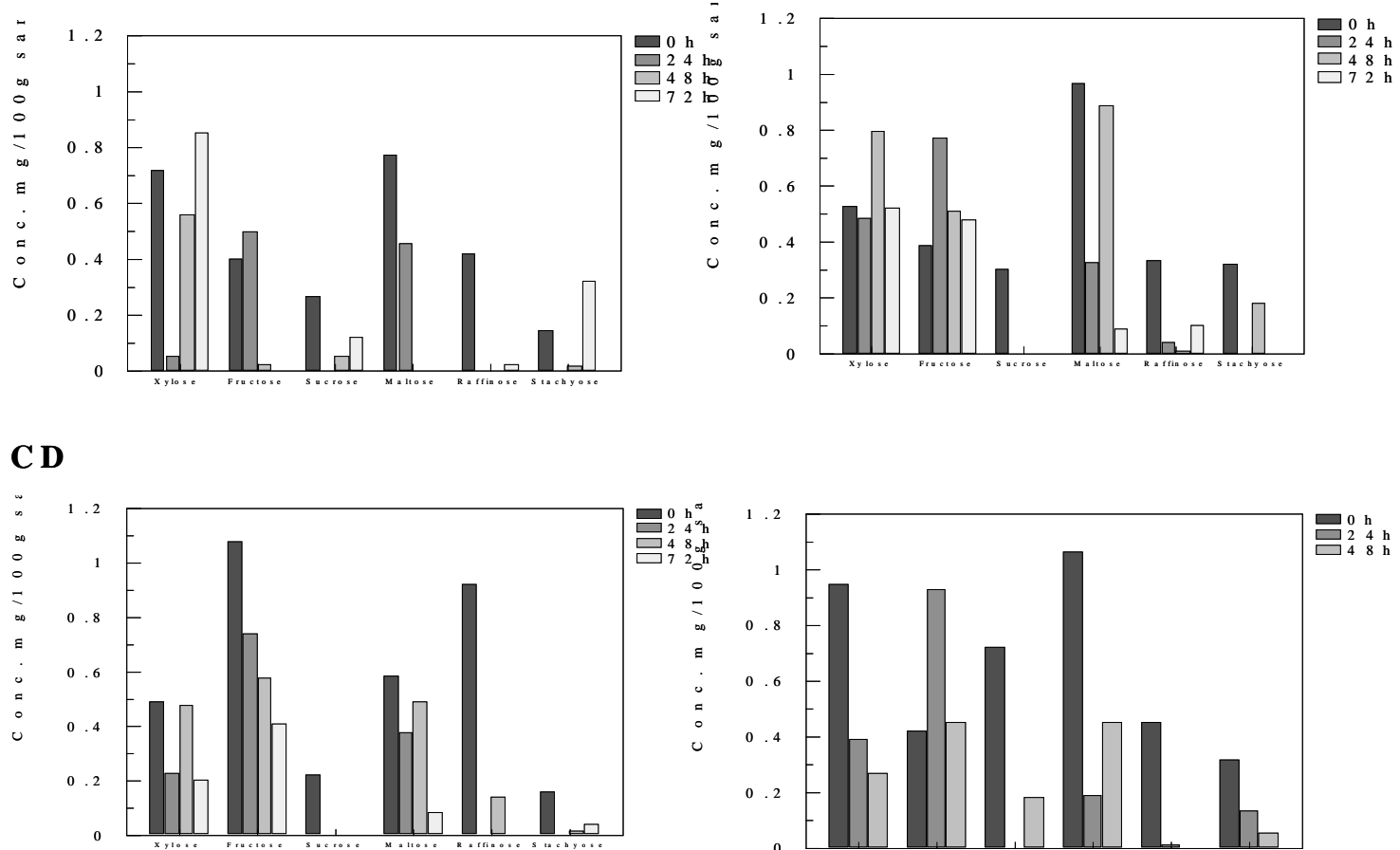

Figure 3. Effect of fermentation on the sugar levels in $5 \%$ (A), $10 \%$ (B), $15 \%$ (C) and $20 \%$ (D) unsteamed cowpea on cofermented maize-cowpea blends

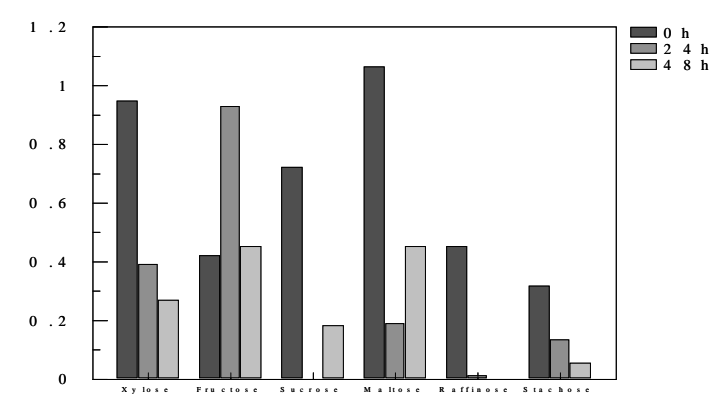


A B
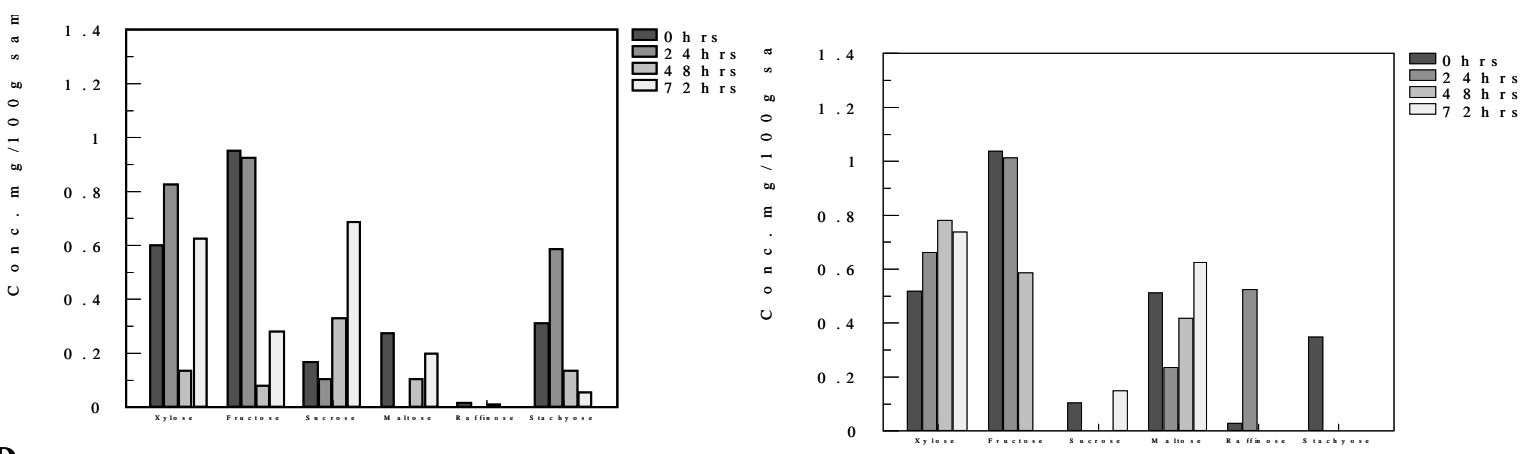

C D
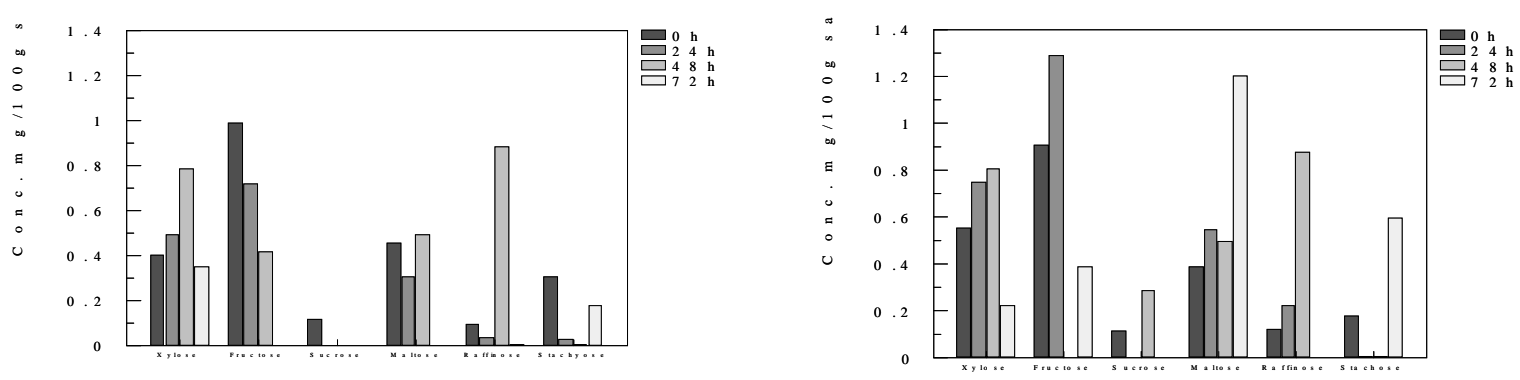

Figure 4. Effect of fermentation on the sugar levels in $5 \%$ (A), $10 \%$ (B), $15 \%$ (C) and $20 \%$ (D) steamed cowpea on cofermented maize-cowpea blends

A B
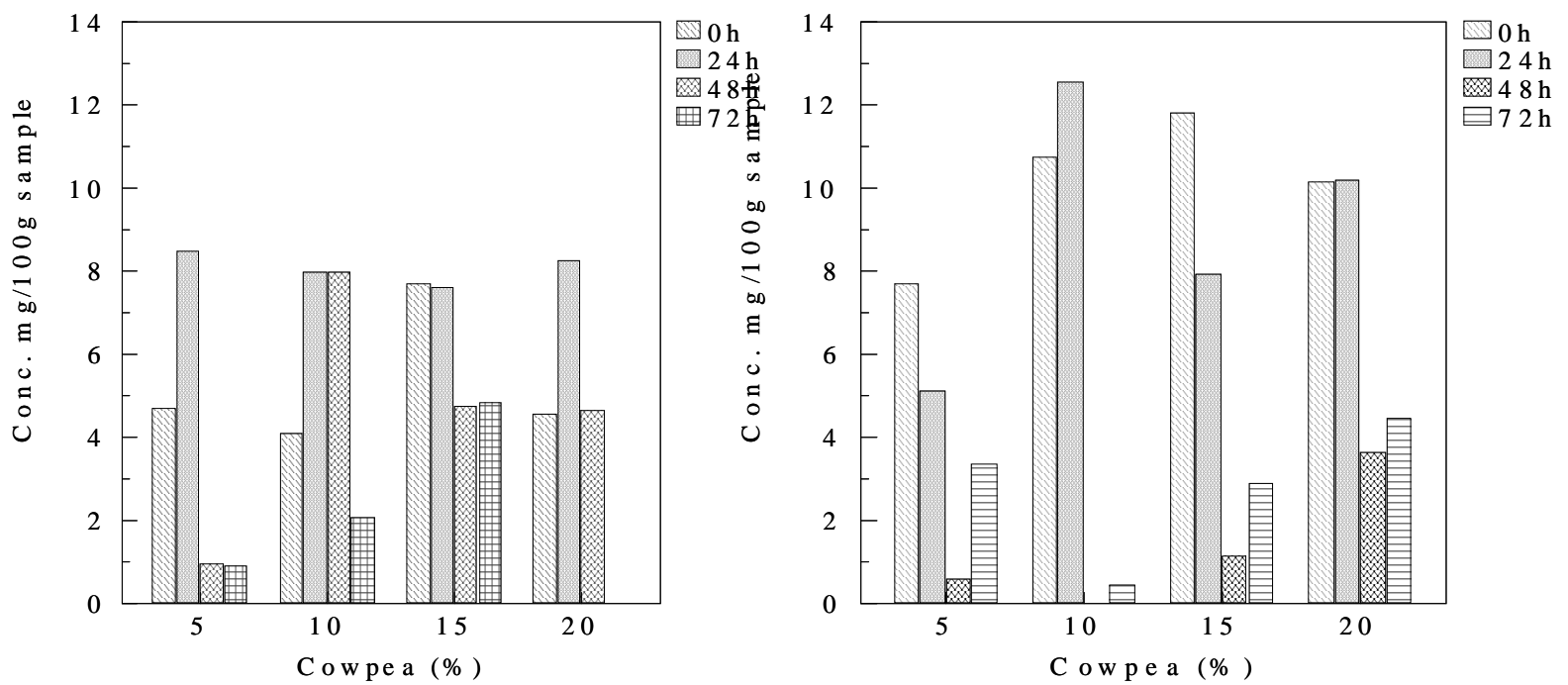

Figure 5. Effect of fermentation on glucose concentration in co- fermented maize-(A) unsteamed and (B) steamed cowpea blends 
Influence of Fermentation and Cowpea Steaming on some

Quality Characteristics of Maize-cowpea Blends

variables on xylose concentration was not conclusive. Xylose was derived from both the maize and cowpeas. The co-fermentation of maize with steamed cowpeas (10, 15 and 20\%) appeared to increase the xylose concentration (Figs. 4B, C \& D) up to $48 \mathrm{~h}$ of fermentation after which a decrease was observed. The system containing unsteamed cowpeas however showed a consistent decrease in xylose concentration with the $20 \%$ cowpea-fortified system (Fig. 3D). The sugars which are derived solely from cowpeas ; sucrose, raffinose and stacchyose seemed to be affected by fermentation. A general decrease with fermentation and complete removal were observed. The sugars predominantly from maize, being glucose/galactose (Fig. 5), maltose and fructose (Fig. 3 \& 4) showed a general reduction with fermentation. Steaming of cowpeas appeared to assist this reduction.

\section{Blend after maize fermentation}

This system showed an interesting trend. Sugars such as sucrose, raffinose and stacchyose derived solely from cowpeas showed great reduction in concentration with fermentation time (Figs. $6 \& 7$ ). This reduction was more pronounced in the 5,10 , and $15 \%$ cowpea-fortified fermented maize system. Apart from xylose, all other sugars being glucose/galactose (Fig. 8), fructose and maltose showed a general reduction with process variables. The data suggest that the fermented maize dough with its 50$55 \%$ moisture is an important media for the reduction of sugars and oligosaccharides derived from cowpeas. It is proposed that the reactions involving the sugars and oligosaccharides from cowpeas may have occurred from the time of mixing with the fermented maize dough to the early part of drying at $65^{\circ} \mathrm{C}$.

The data from the two fermented maize-cowpea systems was subjected to analysis of variance. Table 4 is a summary of the significant F-values from the analysis. Xylose was affected by any of the process variables. Fermentation time had a significant effect $(\mathrm{p} \leq 0.05)$ on fructose, glucose/ galactose, maltose, raffinose and stachyose concentrations (Table 4). The level of cowpeas in the blend affected the glucose/galactose and stachyose concentrations. Steam treatment affected only the maltose concentration. Significant interactions were found between fermentation time and all other process variables.

Table 4. Table of significant F-ratios of mono-, di- and oligosaccharides fermented weaning foods

\begin{tabular}{|lccccc|}
\hline $\begin{array}{l}\text { Process } \\
\text { variables }\end{array}$ & Fructose & $\begin{array}{l}\text { Glucose }+ \\
\text { Galactose }\end{array}$ & Maltose & Raffinose & Stacchyose \\
\hline Fermentation time & 43.079 & 48.972 & 3.501 & 5.142 & 20.372 \\
Fortification level & - & 4.074 & - & - & 10.453 \\
Steam treatment & - & - & 5.400 & - & - \\
\hline
\end{tabular}

\section{Water absorption capacity}

Process treatments of raw material are known to affect their hydration properties (Philips et al., 1988). Water absorption capacity was measured at room temperature $\left(26^{\circ} \mathrm{C}\right)$ to determine the behaviour of the cereal-legume flours in cold water. This is an important index which can give valuable information on the behaviour of the blend during processing. Addition of cowpea improved the water absorption potential of fermented maize dough (Table 6). This was probably due to the influence of added protein in the blends. Proteins are mainly responsible for the bulk of water uptake and to a lesser extent the starch and cellulose at room temperature. Sefa-Dedeh and Osei (1994) made similar observations on a cowpea fortified fermented maize dough system.

Steam treatment of cowpeas was observed to increase its water absorption capacity from $166.8349 \%-221.9613 \%$. For the unfermented and 24-hour fermented maize-cowpea blends, steam treatment of cowpea seemed to cause a decrease in water absorption potential.

Table 5. Water absorption capacities of fermented maize-unsteamed cowpea blends (\% dry matter basis)

\begin{tabular}{|c|c|c|c|}
\hline $\begin{array}{l}\text { Fermentation } \\
\text { time (Hours) }\end{array}$ & Cowpea level (\%) & $\begin{array}{c}\text { Water absorption } \\
\text { of co-fermented } \\
\text { blends }\end{array}$ & $\begin{array}{c}\text { Water absorption } \\
\text { of fermented } \\
\text { blends }\end{array}$ \\
\hline & 0 & 114.6731 & 114.6731 \\
\hline \multicolumn{4}{|l|}{0} \\
\hline & 5 & 142.6048 & 136.6179 \\
\hline & 10 & 143.3218 & 140.0624 \\
\hline & 15 & 144.9571 & 140.5073 \\
\hline & 20 & 137.3242 & 146.1079 \\
\hline & 0 & 118.6975 & 118.6975 \\
\hline \multicolumn{4}{|l|}{24} \\
\hline & 5 & 124.1301 & 132.2226 \\
\hline & 10 & 124.2137 & 139.5657 \\
\hline & 15 & 121.8473 & 146.8565 \\
\hline & 20 & 134.0411 & 133.8545 \\
\hline & 0 & 120.7402 & 120.7402 \\
\hline \multicolumn{4}{|l|}{48} \\
\hline & 5 & 127.1835 & 133.3353 \\
\hline & 10 & 130.1206 & 145.6074 \\
\hline & 15 & 134.2309 & 128.7172 \\
\hline & 20 & 137.0246 & 143.9276 \\
\hline & 0 & 114.2845 & 114.2845 \\
\hline \multicolumn{4}{|l|}{72} \\
\hline & 5 & 122.7185 & 143.0052 \\
\hline & 10 & 136.0395 & 131.9409 \\
\hline & 15 & 138.8273 & 132.8310 \\
\hline & 20 & 139.9509 & 144.3295 \\
\hline
\end{tabular}

However, 48 hours and 72 hours of fermentation the steamed cowpea fortified blends had higher water absorption capacities. Sefa-Dedeh and Demuyarko (1994) reported that 

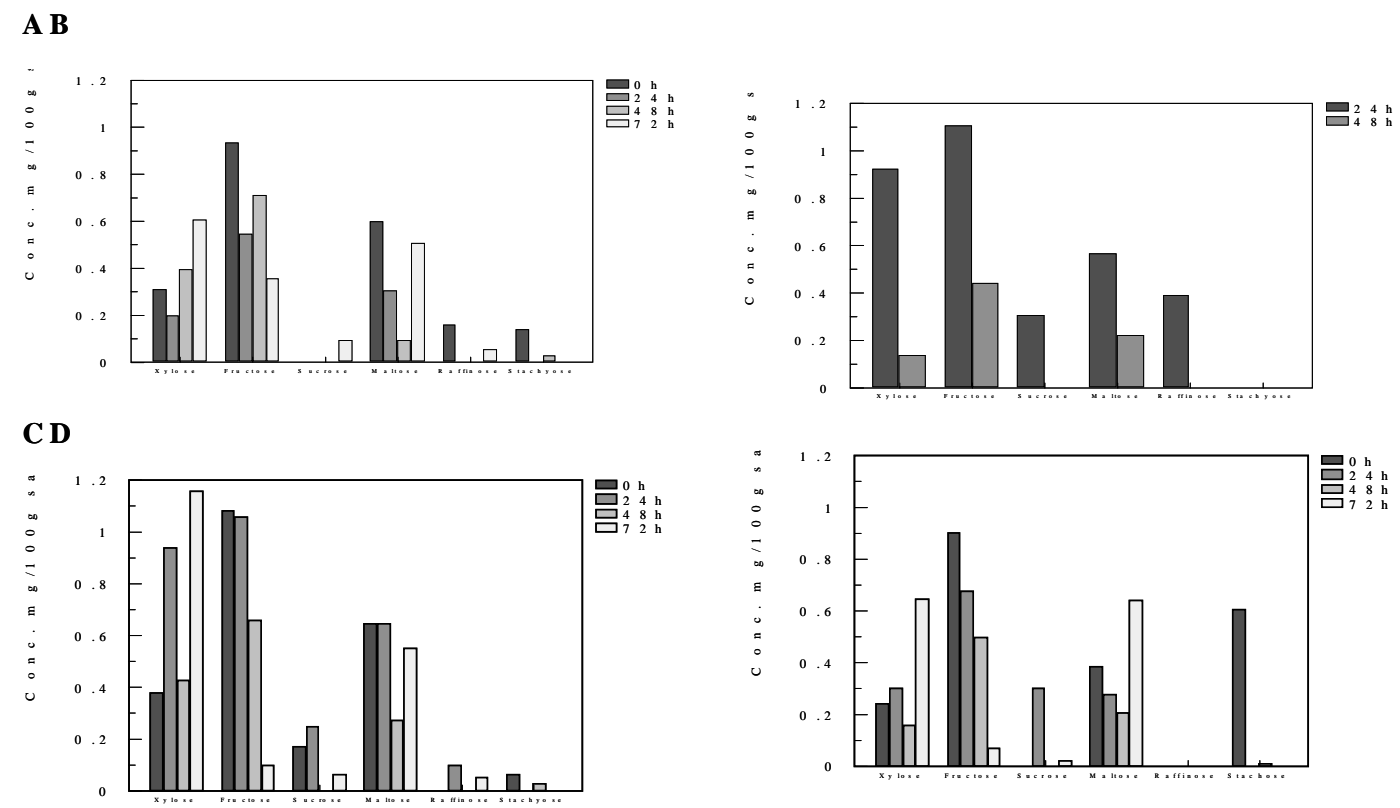

Figure 6. Effect of fermentation on the sugar levels in5\% (A), 10\% (B), 15\% (C) and $20 \%$ (D) unsteamed cowpea on fermented maize- cowpea blends

A B
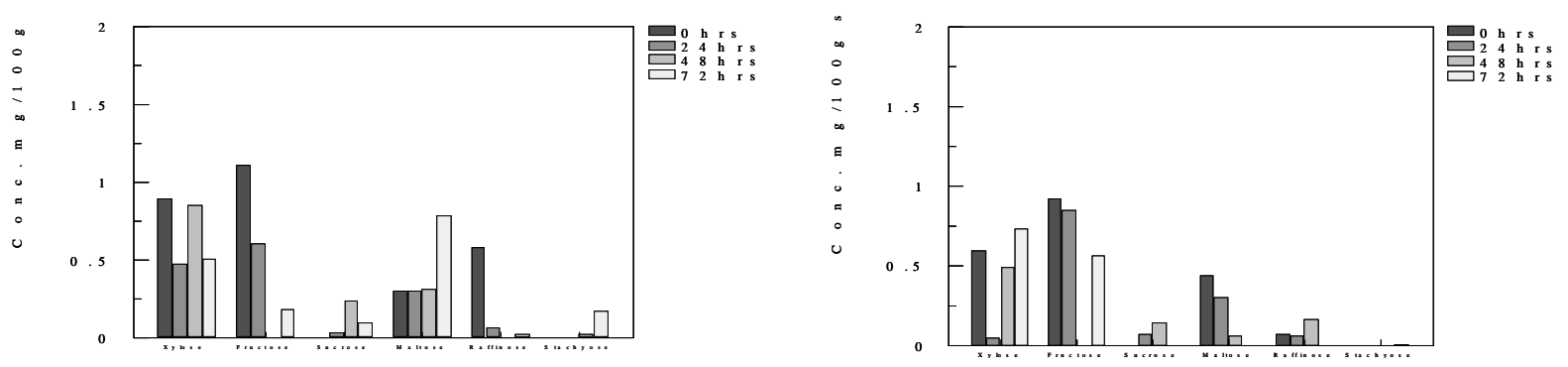

C D
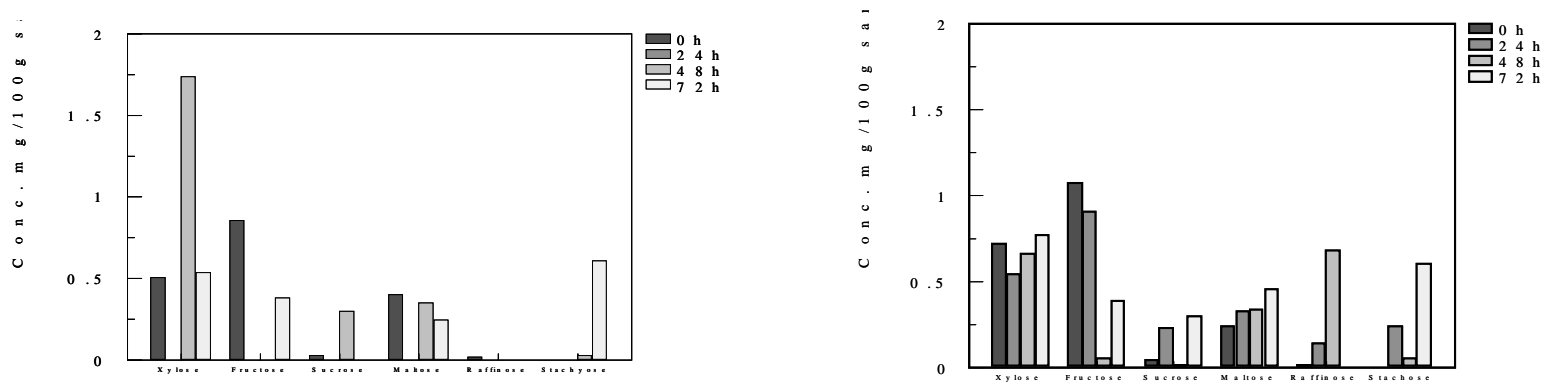

Figure 7. Effect of fermentation on the sugar levels in5\% (A), $10 \%$ (B), $15 \%$ (C) and $20 \%$ (D) unsteamed cowpea on fermented maize- cowpea blends 

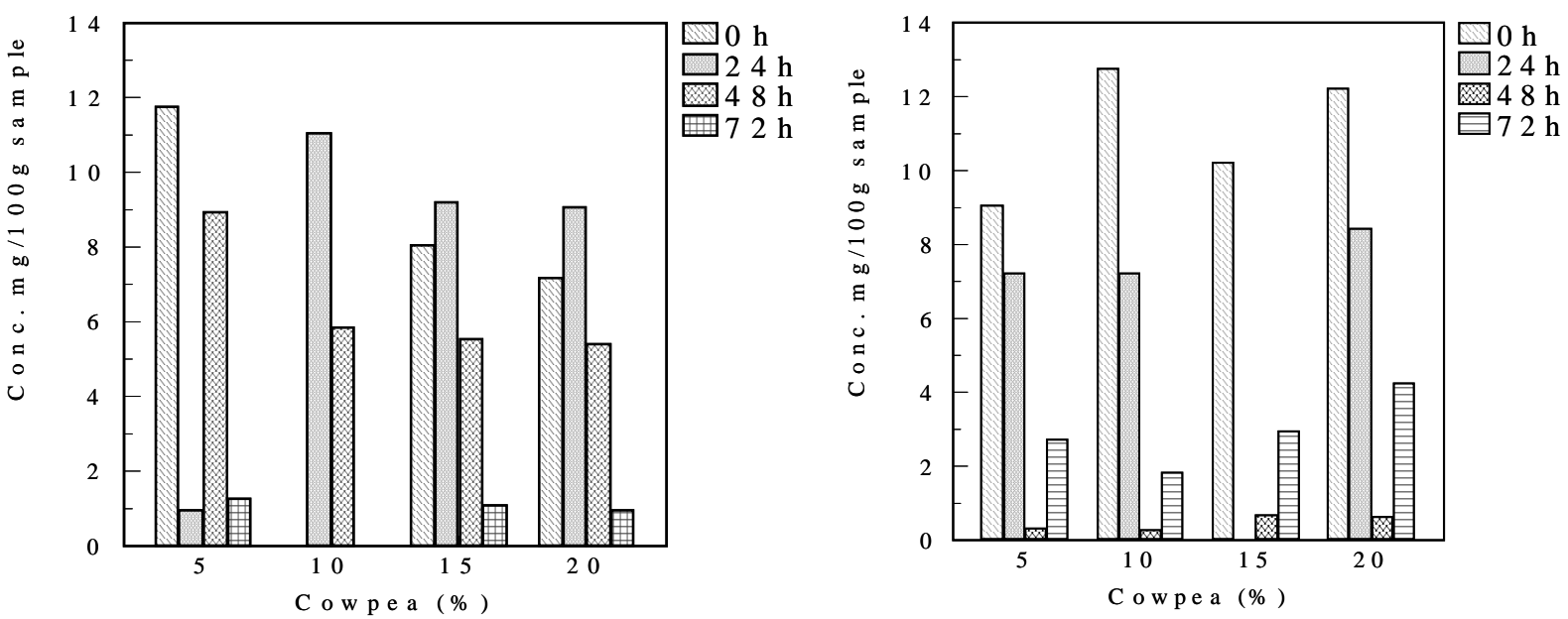

Figure 8. Effect of fermentation on glucose concentration in fermented maize- (A) unsteamed and (B) steamed cowpea blends

steamed cowpea flour possessed better water absorption than raw cowpea flour.

Table 6. Water absorption capacities of fermented maize-steamed cowpea blends (\% dry matter basis)

\begin{tabular}{|c|c|c|c|}
\hline $\begin{array}{l}\text { Fermentation } \\
\text { time (Hours) }\end{array}$ & Cowpea level (\%) & $\begin{array}{c}\text { Water absorption } \\
\text { of co-fermented } \\
\text { blends }\end{array}$ & $\begin{array}{c}\text { Water absorption } \\
\text { of fermented } \\
\text { blends }\end{array}$ \\
\hline & 0 & 114.6731 & 114.6731 \\
\hline \multicolumn{4}{|l|}{0} \\
\hline & 5 & 121.1686 & 129.8615 \\
\hline & 10 & 121.7534 & 135.8566 \\
\hline & 15 & 121.8169 & 133.2053 \\
\hline & 20 & 135.1617 & 140.4852 \\
\hline & 0 & 118.6975 & 118.6975 \\
\hline \multicolumn{4}{|l|}{24} \\
\hline & 5 & 115.4199 & 125.4236 \\
\hline & 10 & 130.6627 & 122.1084 \\
\hline & 15 & 113.3782 & 115.4199 \\
\hline & 20 & 136.0908 & 133.6514 \\
\hline & 0 & 120.7402 & 120.7402 \\
\hline \multicolumn{4}{|l|}{48} \\
\hline & 5 & 136.2266 & 137.4582 \\
\hline & 10 & 142.3521 & 146.7009 \\
\hline & 15 & 147.8524 & 148.1080 \\
\hline & 20 & 144.1065 & 152.9293 \\
\hline & 0 & 114.2845 & 114.2845 \\
\hline \multicolumn{4}{|l|}{72} \\
\hline & 5 & 148.5680 & 138.0563 \\
\hline & 10 & 129.3342 & 149.2652 \\
\hline & 15 & 148.3491 & 148.0684 \\
\hline & 20 & 134.0860 & 153.3773 \\
\hline
\end{tabular}

The gelatinization of starch and the denaturation of protein that is the result of the application of heat treatment to cowpeas has been suggested to improve the water imbibing capacity of cowpea and mung bean proteins
(Abbey \& Ibeh,1988; del Rosario \& Flores, 1981). Analysis of variance indicated that cowpea fortification level and the water absorption capacity of the blends. The effects of steaming the cowpeas prior to its incorporation into the maize dough was not statistically significant (Table 1).

\section{CONCLUSION}

Fermentation and steam cowpea fortification can be used to produce high protein weaning foods with reduced antinutritional factors without significant changes in product quality profiles of the fermented weaning foods.

\section{ACKNOWLEDGEMENT}

This study was funded through the Bean-Cowpea Collaborative Research Support Program by the United States Agency for International Development - Grant No. DAN-1310-G-SS-6008-00.

\section{REFERENCES}

Abbey, B. W., \& Ibeh, G. O. (1988). Functional properties of raw and heat processed cowpea (Vigna unguiculata, Walp.) Flour. Journal of Food Science 53: 1775.

Abdul-Gawad, A. S. (1992). Effect of domestic processing on oligosaccharide content of some dry legume seeds. Food Chemistry 46 :25-30.

Afoakwa, E. O. (1996). Storage characteristics and quality evaluation of cowpea-fortified traditional foods. B.Sc. dissertation. Department of Nutrition and Food Science, University of Ghana, Legon-Accra, Ghana. 
Akinrele, I. A. (1970). Fermentation studies on maize during the preparation of traditional African starch-cake food. Journal of Science of Food and Agriculture $21: 619-625$.

Akinyele, I. O., \& Akinlosotu, A. (1991). Effects of soaking, dehulling and fermentation on the oligosacchrides and nutrient content of cowpeas (Vigna unguiculata ). Food Chemistry $41: 43-53$.

Akpapunam, M. A., \& Sefa-Dedeh, S. (1995). Traditional lactic acid fermentation, malt addition and quality development in maize-cowpea weaning blends. Food and Nutrition Bulletin 16: 75-80.

Brown, K. H. (1991). The importance of dietary quality versus quantity for weanlings in the developed countries: A Framework for Discussion. Food and Nutrition Bulletin 13 (2):86-93.

del Rosario, R. R., \& Flores, D. M. (1981). Functional properties of four types of mung bean flour. Journal of Science of Food and Agriculture 32:175-180.

Fleming, S.E. 1980. Measurement of hydrogen production in the rat as an indicator of flatulence activity. Journal of Food Science $45: 1012-1018$.

Havel, E., Tweeten, T.N., Seib, P.A., Wetzel, D.L., and Liang, Y.T. 1977. Oligosaccharides released during hydration of textured Soy as determined by High Performance Liquid Chromatography. Journal of Food Science 42 (3): 666-668.

Ljungqvist, B.G., Mellander, O. \& Svanberg, U. (1981). Dietary bulk as a limiting factor for nutrient intake in pre-school children. A problem description. Journal of Tropical Pediatrics 27 : 68-73.

Merero, L. N., Payumo, E. N., Aguinaldo, A. R. \& Homma, S. (1980). Malto-oligosaccharide composition of flours, weaning foods and gruels prepared from germinated rice, corn, mungbean and cowpea. Journal of Nutritional Science and Vitaminology 36 (1): 55-64.

Mensah, P. P. A., Tomkins, A.M., Drasar, B. S., \& Harrison,T. J. (1990). Fermentation of cereals for reduction of bacterial contamination of weaning foods in Ghana. Lancet 336 (8708) :140-143.

Obiri-Danso, K. (1994). Microbiological Studies on corn dough fermentation. Cereal Chemistry 71 (2):186188.

Plahar, W. A., \& Leung, H. K. (1982). Effect of moisture content on the development of carboxylic acids in traditional maize dough fermentation. Journal of Science of Food and Agriculture 33:555-559.

Phillips, R. D., Chinnan, M. S., Branch, A. L., Miller, J., \& McWatters, K. H. (1988). Effects of pretreatment on functional and nutritional properties of cowpea meal. Journal of Food Science 53 (3): 805-809.

Sefa-Dedeh, S. (1984). An old processing method, a new protein food. Food and

Nutrition Bulletin 6 (1): 77-80.

Sefa-Dedeh, S. (1991). Improvements of cereal and root crop processing in Africa. In: Book of Abstracts, $8^{\text {th }}$ World Congress of Food Science and Technology. pp. 12-14.

Sefa-Dedeh, S., \& Demuyarko, B. (1994). Effects of steaming and storage on physico-chemical properties of cowpea (Vigna unguiculata) seeds and flour. Paper presented at the Annual Meeting of the Institute of Food Technologists, Atlanta, Georgia, 25 - 29 June, 1994.

Sefa-Dedeh, S., \& Osei, A.K. (1994). Application of response surface methodology to cowpea fortification of a fermented cereal steamed cake. A paper presented at the Annual Meeting of the Institute of Food Technologists, Atlanta, Georgia, 25-29 June, 1994.

Sefa-Dedeh, S., Sakyi-Dawson, E., \& Sanni, A. I. (1999). Microbiology of cowpea-fortified fermented maize dough. Presented at the International Conference on Cowpea Research, Accra, Ghana, 25-29 January, 1999.

Sefa-Dedeh, S., Frimpong, K., Afoakwa, E.O., \& SakyiDawson, E. (2000). Cowpea fortification of traditional foods. Presented at the World Cowpea Research Conference III, Ibadan, Nigeria, 4-7 September 2000.

Sefa-Dedeh, S.. \& Cornelius, B. (2000). The microflora of fermented nixtamalized corn.. Presented at the Annual Meeting of the Institute of Food Technologists, Dallas, Texas. 20-25 June, 2000.

Sefa-Dedeh, S., Sakyi-Dawson, E., Afoakwa, E.O., AndohKumi, K. \& Tano-Debrah, K. (2001). Effect of drying method, packaging material and storage on the quality of cowpea-based weaning foods. Presented at the Annual Meeting of the Institute of Food Technologists, New Orleans, 25-29 June, 2001.

Sosulski, F.W., Elkowicz., \& Reichert, R.D. (1982). Oligosaccharides in eleven Legumes and their airclassified protein and starch fractions. Journal of Food Science 47 (2):498-502. 